\title{
La sección francesa del CEDI: aportaciones a un proyecto europeo $(1952-1964)^{*}$
}

\author{
Antonio Cañellas Mas \\ Universidad de Alcalá/CIDESOC \\ acanellasmas@gmail.com
}

RESUMEN: El Centro Europeo de Documentación e Información (CEDI) en Francia desarrolló una intensa labor en la formación de un ideario compartido por las distintas secciones nacionales en el que despuntaría el concepto de la «Europa de las patrias». Los integrantes de la delegación francesa, adscritos en su mayoría al movimiento político liderado por De Gaulle, mediaron en su intento por encajar a España en la CEE. El ascenso progresivo de los franceses en la dirección del CEDI (1962-1964) nos obliga a recurrir a varias fuentes documentales, entre las que sobresalen el archivo personal del que fuera su presidente, Edmond Michelet, y el fondo de Alfredo Sánchez Bella como uno de sus principales promotores. Se trata de determinar las estrategias y los grados de colaboración en un proyecto de Europa que se apoyaría en la reivindicación de los valores cristianos a partir de una óptica conservadora.

\section{Palabras clave: Europa de las Patrias; Democracia Cristiana; Sub- sidiariedad; Gaullismo; Franquismo; Europeísmo.}

* Siglas utilizadas: Archivo General de la Universidad de Navarra/Fondo Alfredo Sánchez Bella (AGUN/ASB), en las citas correspondientes a este archivo no figuran los números de caja al encontrarse el fondo en proceso de catalogación; Archive Edmond Michelet (AEM); Archives Diplomatiques de France, Nantes (ADF); Archivio Ministero degli Affari Esteri (AMAE). Nuestro agradecimiento a los responsables del Centre d'Études et Musée Edmond Michelet por la asistencia prestada en la consulta de su fondo documental. También valga este reconocimiento para Patrick Breeze, por colaborar en la selección de legajos de los Archives Diplomatiques en Nantes. 


\section{The French Section of CEDI: Contributions to a European Project (1952-1964)}

ABSTRACT: The European Centre of Documentation and Information (CEDI) in France undertook an ambitious project of articulating a single conceptual framework shared by the various national sections in which the concept of "Europe of nations» would play an important role. The members of french delegation, most of whom were attached to the political movement led by De Gaulle, played an important role in creating a space for Spain within the EEC. Given the gradual rise of the French in the direction of CEDI (1962-1964), we are compelled to turn to various documentary sources, such as the personal archives of its president Edmond Michelet, and one of its principal promotors, Alfredo Sánchez Bella. We seek to identify the strategies and the degrees of collaboration of CEDI in a European project, supported on the claim of Christian and conservatives values.

KEY WORDS: $\quad$ Europe of Nations; Christian Democracy; Subsidiarity; Gaullism; Francoism; Europeism.

\section{INTRODUCCIÓN}

Tal como apuntaron los trabajos pioneros de Antonio Moreno Juste y los desarrollados con posterioridad por Petra María Weber, el proyecto del CEDI fue concebido por el Ministerio español de Asuntos Exteriores como una plataforma para promover la diplomacia paralela o informal, pensada para un acercamiento efectivo a Europa ${ }^{1}$. Una estrategia que consistía en el patrocinio público de iniciativas de carácter cultural en las que subyacía una clara intencionalidad política. Ciertamente, su objetivo pasaba por superar el bloqueo internacional sobrevenido después de la Segunda Guerra Mundial, sin renunciar por ello a una difusión simultánea del ideario que animaba al régimen de Franco. De ahí que en el contexto de la Guerra Fría se incidiera en su contenido católico, tradicional y anticomunista para hacerlo más aceptable entre la opinión pública europea. Unos principios que, a pesar de la pluralidad y particularismo de cada centro nacional del CEDI, conformarían el denominador común de sus distintas delegaciones. Es aquí donde la sección francesa suscita un interés especial por el protagonismo adquirido en el seno de la organización a partir de 1962 con la presidencia internacional de uno de los hombres fuertes del gaullismo, Edmond Michelet. En este ascenso progresivo hacia la dirección del CEDI, cabe detenerse en varios puntos de análisis como el referido a los orígenes de esta sección para intentar comprender los motivos de sus relaciones con los representantes españoles. Nuestro cometido incidirá en

1 PEREIRA, 2010: 77-78. 
los aspectos políticos de las relaciones interpersonales. Se trata, en último término, de determinar la influencia que en cada momento pudieron ejercer las principales secciones nacionales en el itinerario del CEDI. En este sentido, cabe preguntarse si existió una rivalidad interna por el control de dicho organismo o ¿el cambio de dirección respondía a una remodelación estratégica con unos fines políticos muy precisos? Todo ello sin olvidar los hipotéticos efectos que pudieron producirse en el CEDI a raíz del relevo experimentado en su presidencia internacional. Una cuestión que exigirá desentrañar cuáles fueron las líneas maestras de la gestión de Edmond Michelet durante su mandato hasta 1964. Toda una serie de interrogantes que aspiramos a contestar, sin perder de vista las repercusiones que pudieron tener las propuestas y acciones del CEDI para los intereses de España.

\section{ORÍGENES DE UNA FUNDACIÓN}

Aunque la idea embrionaria del CEDI había anidado en el parecer de algunas personalidades del catolicismo español, plenamente implicadas en la consolidación del régimen, contó también con el respaldo inicial de ciertos grupos franceses. Fue a finales de los años cuarenta cuando se sentaron las bases para la articulación del CEDI a partir de la plataforma logística que ofrecía el Comité Internacional para la Defensa de la Civilización Cristiana, creado en París en 1948 por Paul Lesourd, antiguo colaborador del gobierno de Vichy². Este organismo, pensado para combatir política y culturalmente la influencia del comunismo en Occidente, inauguraría una delegación en España apenas un año después de constituirse. Como venía aconteciendo desde la llegada del presidente de la Junta Nacional de Acción Católica - Alberto Martín Artajo- al Ministerio de Asuntos Exteriores en 1945, se había activado un operativo para disminuir la hostilidad de las democracias europeas, remarcando la faceta católica y anticomunista del régimen ${ }^{3}$. Máxime cuando los partidos de inspiración democristiana habían alcanzado posiciones importantes en el panorama político europeo. Ciertamente, el recurso a la solidaridad católica en el contexto de la posguerra no ocultaba la disparidad ideológica entre los grupos de inspiración cristiana. En su caso, los ligados a una visión tradicionalista consideraban imposible una cristianización de la democracia moderna ${ }^{4}$, porque para ellos el reconocimiento del pluralismo ideológico y de la voluntad general constituían dos factores claves para dividir a la sociedad y subver-

2 MORENO JUSTE, 2005: 207.

3 PAYNE, 1987: 362.

${ }^{4}$ FOGARTY, 1964: 83. MAYEUR, 1980: 11. 
tir el orden moral ${ }^{5}$. La asunción de esta tesis por buena parte de los dirigentes del catolicismo español, implicaba un escollo en la fluidez de las relaciones con algunos exponentes de la democracia cristiana europea. Sin embargo y apoyándose en el magisterio pontificio sobre la democracia, que admitía la variedad de modelos siempre que no negaran el origen divino de la autoridad y sus límites implícitos ${ }^{6}$, los católicos franquistas intentaron adaptar el régimen a las directrices del derecho público cristiano para justificar su propia actuación ${ }^{7}$. En realidad, aspiraban a entroncar con una tradición de pensamiento que consideraba el sustrato religioso como eje determinante de la nación. De ahí que, como ha señalado Santos Juliá, se produjera una auténtica exaltación de lo católico como instancia única de reconstrucción de la comunidad moral ${ }^{8}$. Esta reivindicación actuaría como elemento definidor de la conciencia nacional española y núcleo de su personalidad en Europa. Según estos sectores, el régimen de Franco representaba una ocasión inmejorable para emprender la restauración católica de la cultura española. Entre otras cosas, porque permitiría exportarla al resto del continente y restituir así los fundamentos cristianos de su antigua unidad, creando las condiciones necesarias para la integración de España en dicho espacio ${ }^{9}$. De este modo se procedería a lo que Moreno Juste ha denominado la retorsión del lema orteguiano: Europa sería ahora el problema, mientras que España se convertiría en su solución ${ }^{10}$. Este proceso de adaptar Europa a los moldes ideológicos asumidos por España para acelerar su integración, fue la causa a la que se dedicaron los promotores del CEDI ${ }^{11}$. Para tal fin, el presidente de la Asociación Católica Nacional de Propagandistas (ACNdP), Fernando Martín Sánchez-Juliá, invitó al entonces director del Instituto de Cultura Hispánica - Alfredo Sánchez Bella-, en su condición de socio propagandista y delegado del Comité español para la Defensa de la Civilización Cristiana, a contactar con sus homólogos franceses. Con la inauguración de una sección nacional del Comité Internacional se dispusieron los medios para una mayor presencia española en los círculos del catolicismo europeo. Una oportunidad que, en opinión de Sánchez-Juliá, no debía desaprovecharse. No sólo para reforzar la posición de los católicos franquistas, sino como instrumento para difundir sus propias ideas

5 FERNÁNDEZ MIRANDA, 1950: 69.

${ }^{6}$ PÍO XII, 1944 (1967): 371.

7 TUSELL, 1984: 85-87.

8 JULIÁ, 40 (Madrid, 2000): 96.

9 PRADES, 66 (Madrid, 2007): 189 y SESMA LANDRÍN, 30 (Bilbao, 2005): 168.

${ }^{10}$ MORENO JUSTE, 2005: 187.

${ }^{11}$ Un ejemplo ilustrativo sobre esta cuestión fue la influencia ideológica que pareció ejercer el régimen franquista en la sección alemana del CEDI, caracterizada por sus planteamientos conservadores y organicistas, tal como indicaría WEBER, 188 (Madrid, 1994): 1097. Unas coincidencias que también reconocería SÁNCHEZ BELLA, 14 (Madrid, 1985): 293. 
en un momento en que se sucedían varias propuestas que aspiraban a definir el proyecto de construcción europea ${ }^{12}$.

Si pocos años antes el presidente de la ACNdP había valorado el papel que Sánchez Bella podía desempeñar en el impulso de campañas culturales para la formación católica de las conciencias ${ }^{13}$, lo mismo cabía esperar a otros niveles como en Pax Romana, convertida en una suerte de Internacional Católica de la que actuaría como secretario general durante la presidencia de Joaquín Ruiz Giménez. En efecto, los preparativos y la celebración en 1946 del XIX Congreso de aquella organización en Salamanca contarían con el respaldo logístico del Ministerio de Asuntos Exteriores. Su interés se fundaba en impulsar, por cauces no oficiales, el contacto con personalidades influyentes del extranjero para ir restableciendo las relaciones diplomáticas con Occidente. Aunque en aquella ocasión Sánchez Bella procuró movilizar a buena parte de los miembros de la Confederación Interamericana de Estudiantes Católicos (CIDEC) para propagar los principios del catolicismo más tradicional ${ }^{14}$, también ahondó en el trato con algunas de sus amistades europeas asistentes al encuentro. Poco a poco fue forjándose la idea de crear un nuevo grupo europeísta de cuño marcadamente español, que actuara como instrumento transmisor de su noción de Europa. El propósito no consistía ya en adherirse a otras iniciativas que pudieran responder más o menos a los parámetros ideológicos con los que se identificaban esas élites del catolicismo español. Al contrario de lo que había acontecido con el Comité para la Defensa de la Civilización Cristiana, ahora se trataba de articular un movimiento propio al servicio del régimen y que se ciñera estrictamente al criterio de sus impulsores.

Tal como había ocurrido con el Congreso de Pax Romana en Salamanca, se pensó que la convocatoria en Barcelona del Congreso Eucarístico Internacional previsto para 1952 representaba la oportunidad perfecta para acometer dicha operación. Parecía claro que si se había conseguido encuadrar a destacados representantes del catolicismo hispánico con la creación del Instituto Cultural Iberoamericano en 1946 podría hacerse lo propio a nivel europeo. Para Sánchez Bella, el hecho de que en la capital catalana se dieran cita un elenco de personalidades bien posicionadas en la directiva de algunas agrupaciones europeístas - como era el caso del Archiduque Otto de Habsburgo, al ostentar la vicepresidencia de la Unión Paneuropea presidida por el Conde Coudenhove-Kalergi_-, envalentonó las gestiones del español para atraerlos a su causa. La valoración del cristianismo por parte de la organización decana

\footnotetext{
${ }^{12}$ Carta de Fernando Martín Sánchez-Juliá a Alfredo Sánchez Bella (13/10/1949). AGUN/ASB.

${ }^{13}$ Carta de Fernando Martín Sánchez-Juliá a Alfredo Sánchez Bella (09/07/1942). AGUN/ASB.

${ }^{14}$ REDONDO, 1999, vol. 1: 728.
} 
del europeísmo como nexo común del continente, por encima de diferencias idiomáticas y trayectorias nacionales, suponía un punto de partida favorable para el entendimiento. Aspecto que además se complementaba con una idea federada de Europa para aunarla frente a la amenaza soviética y el intento estadounidense de dominación económica ${ }^{15}$. Unos presupuestos que no contravenían las tesis generales apuntadas por el Comité para la Defensa de la Civilización Cristiana, a partir del cual maniobraría Sánchez Bella en su objetivo por acercarse al Archiduque, del que era conocida su opinión acerca de la importancia que debía corresponder a España en el concierto europeo ${ }^{16}$.

Al recurrir al abogado Jean Violet, con quien compartía militancia en el Comité, Sánchez Bella logró sortear los obstáculos para acceder a Otto de Habsburgo. Desde ese instante, pudo plantear con éxito la fundación de un centro que reuniera a las personalidades más eminentes del pensamiento católico europeo en su objetivo por acometer la restauración efectiva de los principios cristianos en la cultura contemporánea ${ }^{17}$. La correspondencia del Archiduque al llamamiento de Sánchez Bella se concretaría en la celebración de un primer Congreso en Santander en agosto de ese mismo año (1952). Su temática se centraría en el estudio de la situación europea, además de perfilar la estructura y contenido del nuevo organismo. La excelente posición del Archiduque en el ámbito político, cultural y empresarial del continente, lo convertía en pieza clave de lo que anhelaba ser un entramado internacional desde el que patrocinar la inserción de España en el exterior ${ }^{18}$. De ahí que el titular de Asuntos Exteriores terminara presidiendo el encuentro de Santander en el que concurrieron varios profesionales relacionados con el mundo universitario, financiero y periodístico.

La mayoría de ellos invitados por el círculo del Archiduque, entre los que sobresaldrían varios intelectuales franceses procedentes del Instituto Católico de París o la Escuela de Estudios Americanos. También contaría con la presencia de Paul Lesourd en calidad de presidente internacional del Comité para la Defensa de la Civilización Cristiana ${ }^{19}$. De la experiencia se extrajeron una serie de conclusiones remitidas al Ministro Martín Artajo, apenas un mes después de clausurarse el encuentro. Quedaba clara la vertiente conservadora de un informe que secundaba el discurso anticomunista de sus ponentes. Todos ellos abogaban por una asociación capaz de coordinar a los movimientos

15 COUDENHOVE-KALERGI, 2002: 48, 62.

16 PÉREZ-MAURA, 1997: 276.

17 Declaraciones de Alfredo Sánchez Bella en el Seminario de Estudios organizado por el Departamento de Historia de la Universidad de Navarra (13/11/1987).

18 MORENO JUSTE, 1993, 2: 461.

19 Véase la relación completa de asistentes en GAUPP-BERGHAUSEN, 1971: 29-30. 
europeos de signo católico, sin excluir otras confesiones cristianas ${ }^{20}$. Aun así no dudaban en relegar a sus sectores progresistas, acusándoles de complicidad con el marxismo ${ }^{21}$. En este sentido, el informe juzgaba conveniente la elección de España como centro neurálgico de operaciones para establecer los enlaces pertinentes con el resto de fuerzas afines e inaugurar un nuevo orden europeo sobre bases cristianas. Sólo así España podía recabar «la augusta misión de ser el brazo armado de la Cristiandad», en tanto epicentro de todas aquellas agrupaciones espirituales y políticas fundadas sobre el pensamiento católico tradicional ${ }^{22}$.

Cuando a mediados de 1953 decidió adoptarse oficialmente el nombre de Centro Europeo de Documentación e Información, inscribiéndolo en el registro de asociaciones de Munich y celebrar su segundo Congreso en Madrid, el consejo asesor ya estaba formado por destacadas figuras del establishment franquista. Este predominio de España en la directiva del CEDI era el resultado de su autoría. La directa implicación del Ministerio de Exteriores, se debía al valor que le atribuía como medio de asistencia extraoficial para promover una Europa compatible con el sistema político español ${ }^{23}$. Poco tiempo después de iniciar su singladura, el CEDI iría cobrando mayor fuerza a partir de la labor desarrollada por algunas de las secciones nacionales que compondrían su estructura. Tal fue el caso de la delegación francesa, cuyos patrocinadores desplegarían una labor de captación entre varios círculos de poder que la convertiría en una de las más dinámicas del CEDI, hasta el punto de alzarse con su presidencia en 1962. Más aún al comprometer a personalidades ligadas a movimientos políticos en potencial ascenso como el gaullismo que, al asumir responsabilidades de gobierno, apoyarían las actividades de la asociación. También para que actuara como caja de resonancia de los intereses franceses en Europa.

\section{EL CEDI FRANCÉS}

La brevedad con la que cuajó la idea del CEDI en Francia estuvo motivada por varios factores que aceleraron su constitución. En primer lugar, pesaba

${ }^{20}$ La documentación consultada despeja las dudas planteadas en su día por Petra $\mathrm{M}^{\mathrm{a}}$ Weber al preguntarse si desde 1952 el CEDI acordó su «ecumenización» con otras confesiones cristianas no católicas, como aprobaría oficialmente en 1956. En efecto, el combate contra el comunismo actuaría desde la primera hora como fuerza motriz para la superación de posibles divergencias con aquellas comunidades. Véase WEBER, 188 (Madrid, 1994): 1087.

${ }^{21}$ Informe dirigido a S.E el Ministro de Asuntos Exteriores (06/09/1952). AGUN/ASB.

22 Informe dirigido a S.E el Ministro de Asuntos Exteriores (06/09/1952). AGUN/ASB.

${ }^{23}$ Fue este un elemento clave para que España ostentara la presidencia internacional del CEDI hasta 1962, como reconocería el propio José Ignacio Escobar. WEBER, 188 (Madrid, 1994): 1081. 
mucho la trayectoria del Comité para la Defensa de la Civilización Cristiana que, en cierto modo, ya había abierto brecha en suelo francés al agrupar a no pocos elementos conservadores como Claude-Joseph Gignoux, Jean Tracou, Paul Marion o Antonie Pinay. Todos ellos antiguos colaboradores del régimen Vichy ${ }^{24}$, cuya oposición al marxismo y a la democracia liberal les brindó la oportunidad de intentar una recristianización del ordenamiento jurídico ${ }^{25}$. Aunque después de la Segunda Guerra Mundial su principal preocupación se focalizara en combatir la amenaza que para ellos representaba el comunismo en Europa, no dejaron de incidir en la vulnerabilidad de buena parte de los Estados occidentales. Principalmente, por sustentarse sobre unas bases filosóficas que juzgaban endebles, a causa de un pluralismo ideológico que debilitaría la unidad social necesaria para encarar los desafíos de la Guerra Fría ${ }^{26}$. No extraña entonces que surgieran iniciativas tendentes a estrechar la cooperación entre personas y grupos para armar un cuerpo de doctrina lo suficientemente sólido como para inmunizar a la sociedad de la influencia marxista ${ }^{27}$. En esta empresa también se asociarían otros nombres que, a pesar de compartir una misma concepción cristiana de la vida, diferían en cuanto a sus orígenes políticos. Tal fue el caso de François de la Noë, miembro destacado de la resistencia gaullista. Nacido en Vallauris (Alpes-Marítimos) en 1895, hijo del Almirante Charles de la Noë, de quien heredaría el título de Conde, se enrolaría como voluntario en el arma de aviación durante la Gran Guerra, sobresaliendo también por sus estudios filosóficos y teológicos. En ellos analizaría el valor del cristianismo como elemento vertebrador de las distintas comunidades europeas, agrupadas en un espacio de cultura compartido que, siguiendo esa lógica, debía actuar como marco de convivencia y solidaridad ${ }^{28}$. Con ello reivindicaba, en primer lugar, la personalidad histórica de cada una de las naciones europeas, entendidas como partes imprescindibles de un todo al que imprimirían esa identidad común cifrada en los principios cristianos ${ }^{29}$. Esta percepción, asumida por buena parte de los gaullistas, coincidía con la de los

${ }^{24}$ COINTET, 2011: 121, 147, 614, 636.

${ }^{25}$ BONINCHI, 2005: 12-13.

${ }^{26}$ RÉMOND, 1968, vol. 2: 275.

27 CEDI, 1956: 21.

${ }^{28}$ DE LA NOË, 1947; 1949.

${ }^{29}$ Véase al respecto su obra, junto a André Dupeyrat, Sainteté «au naturel» (1957), cuyas reflexiones también transmitiría a Edmond Michelet al ensalzar la realeza de Jesucristo y la de Francia, identificando el sentimiento nacional y religioso. Aspecto que, en última instancia, evocaba el antiguo ideal de cristiandad amoldado al contexto histórico de su tiempo. Una perspectiva de la que participaba el futuro presidente del CEDI, como demostraría en calidad de Ministro de Asuntos Culturales en el homenaje público rendido a san Luis — rey de Francia-, en 1970. Sobre estas cuestiones, lettre de François de la Noë à Edmond Michelet (06/03/1958). AEM, 05.128/04. 
sectores tradicionales del catolicismo, pero difería sustancialmente en cuanto al tratamiento de la cultura moderna. Sobre todo, porque para el gaullismo el lema de la Revolución Francesa engarzaría con los grandes ideales cristia$\operatorname{nos}^{30}$, tal como habían postulado algunos intelectuales de referencia como Paul Claudel, Charles Péguy o Jacques Maritain ${ }^{31}$.

No es casual que la mayoría de aquellos dirigentes se hubieran iniciado políticamente en los círculos de la democracia cristiana, sin por ello pretender una restauración de los esquemas del Antiguo Régimen según las tesis nacionalistas de Charles Maurras. Más bien, aspiraban a articular una síntesis integradora de la historia de Francia ${ }^{32}$. De ahí que se aceptaran los presupuestos democráticos y republicanos, pero jerarquizados con arreglo al principio monárquico del poder que inspiraría la acción presidencialista de la Jefatura del Estado $^{33}$. Este contraste con las corrientes católicas que secundaban la dictadura en España, ajenas a la recepción de los fenómenos revolucionarios por cuanto alterarían una identidad nacional que vinculaban al factor religioso ${ }^{34}$, no obstaculizaría sin embargo la cooperación transpirenaica entre dichos sectores políticos. En principio, porque ambas partes reconocían la particularidad histórica de sus países y la consiguiente diversidad de soluciones que pudieran trazarse ${ }^{35}$. Así lo había entendido François de la Noë y quienes se agruparon en torno a su liderazgo. En su opinión, los valores cristianos debían primar en la definición del concierto europeo, tal como expondría en la conferencia pronunciada en el segundo encuentro que organizó el CEDI en Madrid en septiembre de 1953. Su inclusión por vez primera en un programa mucho más ambicioso que el del año anterior, respondía a un plan preconcebido para articular cuanto antes y de manera estable un centro nacional del CEDI en Francia. Por su residencia habitual en el país, los promotores españoles convinieron con Otto de Habsburgo una distribución de encargos en la que él mismo asumiría las gestiones para crear la sección francesa, mientras que Sánchez Bella se comprometía a hacer lo propio en Italia ${ }^{36}$.

Aunque los cimientos del CEDI francés se habían dispuesto en 1953, a raíz del compromiso adquirido por de la Noë, no empezaría a funcionar hasta el año siguiente y de una forma más bien rudimentaria. En buena medida, porque aún adolecía de la suficiente estructura, limitando su actividad a las ges-

30 Declaraciones de Michelet al Diario de Mallorca (17/11/1963).

${ }^{31}$ FAZIO, 2008: 126-127.

32 La recepción de esta síntesis por parte de Charles De Gaulle en CHARLOT, 1992: 657.

${ }^{33}$ CHARLOT, 1992: 660.

34 ÁLVAREZ JUNCO, 2001: 454.

${ }^{35}$ En este sentido, es ilustrativo el mensaje de Fin de Año pronunciado por Franco en 1959. MORENO JUSTE, 1998a: 31.

${ }^{36}$ Carta de Alfredo Sánchez Bella a Otto de Habsburgo (19/12/1957). AGUN/ASB. 
tiones personales de su máximo responsable. De ahí que hasta el final de la década no se apreciaran novedades sustanciales en su composición, coincidiendo con el ascenso del gaullismo al poder, catapultado por la crisis de Argelia (1958). Un hecho que beneficiaría políticamente al Conde de la Noë y al grupo de disidentes democristianos del Mouvement Républicain Populaire (MRP), expulsados del partido por su adhesión transversal al Rassemblement du Peuple Français (RPF) creado por De Gaulle en 1947. Las relaciones de la Noë y los integrantes de aquella tendencia, facilitó la articulación de un núcleo cada vez más homogéneo que configuraría las líneas maestras del CEDI francés. Sin embargo, el compás de espera inicial estuvo condicionado por la incógnita de cómo evolucionaría la política francesa en ese contexto de crisis generalizada. Eso obligó al Archiduque Otto a calmar los ánimos de Sánchez Bella, impaciente por acelerar el desarrollo del CEDI francés. Y es que, en último término, se trataba de impedir incorporaciones precipitadas a la asociación que luego pudieran carecer de influencia en las instituciones del país ${ }^{37}$. Un aspecto ciertamente capital para los intereses de España si se aspiraba a que su régimen fuera tratado con normalidad por los gobiernos europeos, de los que se esperaba que algunos miembros del CEDI pudieran formar parte, como ocurría con la delegación francesa. Antes de que se produjera el despegue de ese centro nacional, François de la Noë había procurado atraer algunas personalidades de su campo político, que acabarían sustituyendo a los primeros ponentes galos en las sesiones congresuales del CEDI. Poco a poco se fue concediendo mayor protagonismo a políticos en ejercicio como diputados y senadores, en detrimento de académicos o intelectuales en sentido estricto. Y es que, en palabras del Archiduque Otto, reflejo de la filosofía que animaba su actuación y la del CEDI, el intelectual de la era atómica debía ser eminentemente político, por cuanto podía favorecer una transformación efectiva de la cultura y de las instituciones ${ }^{38}$. Así lo entendían también Sánchez Bella, el Conde de la Noë y el entonces presidente ejecutivo del CEDI, José Ignacio Escobar.

Eso explica el interés de la Noë por emplazar a varios profesionales del derecho, de la economía y del ejército en el tercer encuentro internacional del CEDI celebrado en Santander en el verano de 1954 para considerar desde esos ángulos la Construcción federativa de una Europa cristiana $^{39}$, planteada como alternativa al proyecto constitucional de Estrasburgo. Una propuesta que, inscrita en el marco de la Comunidad Europea de Defensa, pretendía alentar la unión política de los Estados miembros, más allá de los esquemas

${ }^{37}$ Carta de Otto de Habsburgo a Alfredo Sánchez Bella (10/01/1958). AGUN/ASB.

${ }^{38}$ HABSBURGO, 62 (Madrid, 1955): 158.

39 Título del III Congreso Internacional del CEDI, en GAUPP-BERGHAUSEN, 1971: 49-67. 
económicos dispuestos por la $\mathrm{CECA}^{40}$. El notable incremento de las competencias de las instituciones europeas en materia de política exterior y la promoción de un modelo liberal en el que debían organizarse políticamente sus Estados, provocó las reacciones opuestas de distintos sectores. En Francia, los votos de comunistas y gaullistas darían al traste con la iniciativa, pero sobre todo revelarían que los argumentos de algunos diputados del RPF coincidían con las mociones aprobadas por el Congreso del CEDI apenas unos meses antes $^{41}$. En ellas se instaba a una entente franco-alemana como eje para una Europa fundada sobre unos presupuestos cristianos en el que se respetaran sus nacionalidades. Se trataba de articular una cooperación de las partes con arreglo al principio de subsidiariedad, según el cual ninguna entidad de orden superior asumiría las funciones de las inferiores siempre que pudieran desempeñarlas por sí mismas ${ }^{42}$.

Este planteamiento de carácter confederal, fue el que ya había manifestado con especial viveza Edmond Michelet en las páginas del diario Le Monde el 20 de marzo de 1954, antes de la inauguración del encuentro del CEDI. En su artículo arremetía contra la idea constitucional de Estrasburgo, asociándola «al peligro de apátridas y tecnócratas» a quienes habían de contraponerse «la resistencia de las patrias» ${ }^{43}$. El líder de los Républicains Populaires Indépendants (RPI), escisión de la democracia cristiana que se integraría en los cuadros políticos del gaullismo, era bien conocido en Francia por su activismo como militante de la Acción Católica en la región de Corrèze. Allí dirigió las acciones de la Resistencia contra el colaboracionismo de Vichy hasta que fue deportado por la Gestapo al campo de Dachau en 1943. Su reclusión durante dos años fue posteriormente premiada por De Gaulle al nombrarle Ministro del Ejército en el gobierno de 1945. Su militancia en el MRP y a partir de 1947 en las filas independientes adscritas al RPF, del que sería diputado entre 1952 y 1958, le convirtió en uno de los exponentes de su corriente democristiana. Una imagen que él mismo cultivaría al participar en organizaciones internacionales como el Conseil pour l'Ordre Chrétien, que aspiraba a cristianizar la legislación francesa y apoyar a otros Estados con iguales pretensiones, como fue el caso de España ${ }^{44}$. Esta capacidad de iniciativa y la confluencia con las conclusiones acordadas por el CEDI en su tercera entrega de 1954, le hacían especialmente apto para atraerlo a la causa de la asociación.

40 PÉREZ-BUSTAMANTE, 1995: 99.

${ }^{41}$ GONZÁLEZ CUEVAS, 13 (Torino, 1998): 53.

42 Véase la intervención de Otto de Habsburgo en el III Congreso del CEDI, en GAUPPBERGHAUSEN, 1971: 65.

${ }^{43}$ CHARBONNEL, 1987: 95.

${ }^{44}$ Lettre du Secretaire Général du Conseil International pour l'Ordre Chrétien à le président du groupe français (03/12/1951). AEM. 04. 279/01-06. 
Sobre todo después de que el Ministerio español de Exteriores manifestara su preocupación por un texto como el de Estrasburgo, cuyas exigencias democráticas podían amenazar el objetivo de acomodar el régimen franquista a la Europa de los Seis. Sin embargo, a juicio de Sánchez Bella, en respuesta a la petición cursada por el Ministro Martín Artajo, aquella dificultad no debía sortearse adoptando una posición defensiva. Al contrario, había que proponer una alternativa real que congregara el interés de otros países europeos coordinados a través del CEDI ${ }^{45}$. De ahí la sugerencia de estudiar pormenorizadamente dicha cuestión en su próximo congreso. En efecto, había que diseñar una nueva proposición, difundiéndola entre los dirigentes europeos más sensibles a los argumentos de la asociación ${ }^{46}$.

Dentro de este plan estratégico y una vez obtenido el plácet del Ministerio, Sánchez Bella encargaría la elaboración de un proyecto a varios expertos españoles en derecho político que delimitara las líneas maestras de lo que debía ser el discurso compartido del CEDI. No ya para detener aquella fórmula de Unión Política europea, que naufragó antes de que se iniciaran las sesiones del III Congreso, sino para captar nuevos y dinámicos colaboradores en cada uno de los centros nacionales que sostuvieran aquella propuesta ${ }^{47}$. Al impulsar esa intensa coordinación en su estreno como presidente del CEDI, Otto de Habsburgo pudo comprobar el grado de correspondencia de sus secciones. De entre ellas, pronto sobresaldría la francesa, debido a los buenos oficios de la Noë, envalentonado por el mayor tono internacional que proyectaba el nombre del Archiduque a la asociación.

Esta nueva imagen y la postura oficial adoptada por el CEDI, despertaría el interés de Edmond Michelet. Tan es así que al poco tiempo aceptaría el ofrecimiento del presidente de la sección francesa para participar como ponente en el IV Congreso de la organización en 1955, donde abordaría el problema de la coexistencia con los países comunistas. Ciertamente, la síntesis entre el concepto gaullista de «la Europa de las patrias» con la visión cristiana heredada del republicanismo popular, convertiría a Michelet en la principal figura en la que pensó François de la Noë para reforzar la estructura francesa del CEDI.

\section{ACTIVIDAD Y DESARROLLO DE UNA DELEGACIÓN}

A partir de 1955 el centro nacional del CEDI en Francia entraría en una fase de mayor dinamismo, favorecida también por la vicepresidencia interna-

\footnotetext{
${ }^{45}$ Carta de Alfredo Sánchez Bella a Alberto Martín Artajo (28/04/1954). AGUN/ASB.

${ }^{46}$ Carta de Alfredo Sánchez Bella a Alberto Martín Artajo (28/04/1954). AGUN/ASB.

${ }^{47}$ Carta de Alfredo Sánchez Bella a Alberto Martín Artajo (28/04/1954). AGUN/ASB.
} 
cional asumida por el Conde de la Noë, que compatibilizaría con sus responsabilidades al frente de la sección gala. El hecho de que se convirtiera en uno de los colaboradores más cercanos del Archiduque en la dirección de aquella empresa, determinaría un progresivo traslado de influencias a suelo francés. En primer lugar, por la implicación de sus miembros en la gestión y actividades de una asociación a la que se irían adhiriendo personalidades que llegarían a ocupar puestos ministeriales en los gobiernos del General De Gaulle. Y, en segundo término, por la conveniencia de los promotores españoles en desplazar el foco de atención fuera de España. En realidad, una campaña de imagen que aspiraba a presentar al CEDI como un movimiento desvinculado de los intereses políticos del régimen. Aunque, en la práctica, nunca se renunció a su instrumentalización en virtud de los fines para los que había sido creado.

En cualquier caso, la preparación del IV Congreso del CEDI en El Escorial, serviría para que de la Noë incorporara a Michelet a sus tareas. La vicepresidencia del centro tenía presente que si aquel dirigente lograba identificarse con esa empresa, su prestigio y dinamismo personal atraerían a otros nombres destacados del panorama político francés. Desde tiempo atrás Michelet conocía la realidad española, tanto por sus contactos con algunos exiliados, con quienes había compartido destino en Dachau, como por su participación en la reunión convocada en España por el Conseil International pour l'Ordre Chrétien en $1952^{48}$. Con estos antecedentes, decidió acudir a un congreso que, aparte de exponer sus criterios sobre la coexistencia pacífica, le ofrecía la oportunidad de estrechar relaciones con otros líderes europeos. En definitiva, se trataba de propagar esa idea gaullista de «la Europa de las patrias», resaltando la supremacía nacional de los Estados en el proceso de integración ${ }^{49}$. Una premisa de la que el régimen de Franco quiso sacar partido para acelerar su acomodo al club de los Seis ${ }^{50}$. Así pues, ya no eran sólo los españoles los que vislumbraban las potencialidades del CEDI para influir en los ambientes del conservadurismo europeo y disponerlos a su favor; también otras delegaciones como la francesa, puesta al servicio del gobierno de París para concitar apoyos a su propuesta de construcción europea.

En su intervención congresual, Michelet se preguntaría cuál debía ser la alternativa de Europa ante el problema de la coexistencia. Para ello había recurrido a las enseñanzas de Pío XII sobre la materia, de las que extrajo varias ideas para estructurar su intervención. De entre ellas, subrayaría las palabras

48 Esta reunión fue motivo de una agria polémica ente Edmond Michelet y Javier Landaburu, presidente de la Liga Internacional de los Amigos Vascos, quien le acusó de colaborar con el régimen de Franco. Un reproche que el francés negaría en su respuesta. Lettres de 29/10/1952 et 03/11/1952, AEM. 04. 279/011/017.

49 MARTÍN DE LA GUARDIA; PÉREZ SÁNCHEZ, 2002: 29.

50 POWELL, 49 (Madrid, 2003): 87. 
que condenaban los excesos nacionalistas, pero sin confundirlos con el honor y derecho de las patrias ${ }^{51}$. Del mismo modo, abundaba en la necesidad de preservar el derecho natural como base para edificar la coexistencia y deshacer las tesis comunistas ${ }^{52}$. Unos presupuestos que le servirían para respaldar su planteamiento sobre la Europa de las 20 naciones, cuya independencia y libertades deberían actuar como nexo común de cohesión frente a las sojuzgadas por el stalinismo ${ }^{53}$. Marcada esta distinción, que excluía a los países del Este, continuaba disertando sobre la forma de articular esa unidad para erigirla en alternativa real al comunismo. A su juicio, no se trataba de plantear soluciones militares en plena era atómica, sino en regenerar cristianamente la cultura europea para alumbrar sistemas políticos socialmente justos y respetuosos con las libertades, que pudieran neutralizar a los Estados marxistas ${ }^{54}$.

Aunque el tema de su conferencia fue sugerido por de la Noë, al preparar los contenidos y el orden de intervenciones de los delegados franceses, Michelet logró integrar en su discurso parte del debate desarrollado en el centro de intelectuales católicos franceses. En la correspondencia con el secretario general del CEDI, José Ignacio Escobar, quien intercambió con Michelet palabras de agradecimiento por corresponder a la invitación del Congreso ${ }^{55}$, subyacía el interés de los próceres del franquismo por atraer a personalidades extranjeras cuya mediación permitiera alcanzar acuerdos con sus respectivos países $^{56}$. El caso de Michelet no sería una excepción al actuar de eslabón con otros militantes del RPF, sugiriendo sus nombres a los responsables del CEDI para que les informaran acerca de sus actividades. No en balde había citado a Louis Terrenoire, secretario general del movimiento gaullista entre 19511954 y futuro Ministro de Información ${ }^{57}$. Un correligionario de origen democristiano del que podía esperarse una previsible adhesión al CEDI. Al proponer a otros dirigentes de su corriente política, Michelet estaba aprobando la labor desarrollada por una asociación con la que cada vez se sentía más identificado a la vista de su recorrido ${ }^{58}$. Así también lo valoraron algunas cancille-

${ }^{51}$ Quelle est 1'alternative pour 1'Europe devant le problème de la coexistence? AEM. 05.123/053-076.

${ }_{52}$ Quelle est l'alternative pour 1'Europe devant le problème de la coexistence? AEM. 05.123/053-076.

${ }^{53}$ Quelle est l'alternative pour 1'Europe devant le problème de la coexistence? AEM. 05.123/053-076.

${ }^{54}$ Quelle est 1'alternative pour 1'Europe devant le problème de la coexistence? AEM. 05.123/053-076.

${ }_{55}$ Carta de José Ignacio Escobar a Edmond Michelet (01/03/1955). AEM. 05. 123/03.

56 SESMA LANDRÍN, 30 (Bilbao, 2005): 167.

${ }^{57}$ Lettre de Edmond Michelet à José Ignacio Escobar (21/05/1955). AEM. 05. 123/015.

${ }^{58}$ Es ilustrativa a este respecto la carta remitida por Edmond Michelet a José Ignacio Escobar a los pocos días de la clausura del Congreso con fecha del 15 de junio de 1955 en la que 
rías europeas como la italiana que, a pesar de clasificar a la asociación de extrema derecha por ser una emanación del Ministerio español de Asuntos Exteriores, admitía sin embargo su creciente importancia en el tablero europeo desde que empezara a actuar como soporte intelectual del discurso gaullista acerca de la «Europa de las patrias» ${ }^{59}$. Es aquí cuando la delegación francesa adquiriría una mayor conciencia del liderazgo que podía asumir en el seno de la organización, al contar con la asistencia de algunas instituciones de la República gestionadas por varios de sus dirigentes. Por su parte, en diversos informes remitidos al Ministro de Exteriores francés - Maurice Couve de Murville - , la embajada en Madrid juzgaba la idoneidad del CEDI en función de la buena acogida que habían tenido las tesis políticas sostenidas por los delegados franceses entre sus participantes, reforzando así el proyecto gaullista de construcción europea ${ }^{60}$.

No obstante, este afán por imprimir su marca frente a otras secciones nacionales ya se había manifestado anteriormente desde que en el Congreso de 1955 François de la Noë mostrara su preocupación por el abultado protagonismo del centro alemán, consecuencia de los contactos de Otto de Habsburgo con la CSU-CDU61. Una cuestión que, a juicio del presidente de la sección gala, exigía un incremento de sus participantes para equilibrar el peso de cada delegación con invitados de la misma categoría que la del presidente del Bundestag ${ }^{62}$. De ahí la acogida de esos consejos por parte de Michelet, quien los transmitiría a José Ignacio Escobar para agregar a nuevos representantes franceses. Tal fue el caso de Terrenoire y otros diputados como Gaubert, Raingearl o Devaud, aparte de los que habían confirmado su asistencia como Michel Habid-Deloncle ${ }^{63}$.

Si bien es cierto que en las reuniones preparatorias se descolgaron algunos de aquellos nombres ${ }^{64}$, no fue óbice para que de la Noë trazara las coordenadas a seguir por la sección francesa en Madrid, dándole una mayor coherencia y unidad interna en su discurso ${ }^{65}$. La rápida movilización operada por el pre-

reconoce la buena orientación del CEDI, comprometiéndose a trabajar en el proyecto con especial intensidad. AEM. 05. 123/045.

${ }^{59}$ AMAE, Uffici Politici, 1945-1960. Versamento I, caja 315.

${ }^{60}$ Note au Ministre des Affaires Étrangères (12/06/1962). ADF 396/PO/F/1-1476. Série IX, $\mathrm{n}^{\mathrm{o}} 1100$.

${ }^{61}$ Es clara la relevancia del círculo Abendland entre los socios alemanes del CEDI, cuya delegación sería una de las más nutridas y activas a causa de su capacidad de organización y apoyos financieros. WEBER, 188 (Madrid, 1994): 1081-1084.

${ }^{62}$ Lettre de François de la Noë à Edmond Michelet (07/05/1955). AEM. 05. 123/08.

${ }^{63}$ Lettre de François de la Noë à Edmond Michelet (07/05/1955). AEM. 05. 123/08.

${ }^{64}$ Entre ellos merecen señalarse a Maupeou y Gaubert, quienes excusaron su asistencia por varios contratiempos de última hora. Lettres à Edmond Michelet. AEM. 05. 123/025/026.

${ }^{65}$ Lettre de François de la Noë à Edmond Michelet (12/05/1955). AEM. 05. 123/09. 
sidente del CEDI francés logró garantizar el equilibrio de las distintas secciones nacionales en El Escorial. Asimismo, se dio cabida a otros ponentes francófonos de origen belga después de que de la Noë asumiera el encargo de crear delegaciones en Bélgica y Holanda. Por el contrario, la falta de resultados por parte de los españoles — que se habían responsabilizado en hacer lo propio con Italia y Portugal ${ }^{66}$ - , confirió al centro francés un aura de eficiencia que lo situaría en la cabecera de las delegaciones del CEDI a finales de los años cincuenta. Más aún cuando en España el cambio de gobierno de 1957 supuso el relevo del titular de Exteriores por Fernando María Castiella, muy poco convencido de la efectividad del CEDI como instrumento de aproximación a Europa ${ }^{67}$. Este cúmulo de factores generaría una breve pero intensa crisis, hasta el punto de plantearse el traslado de la sede a Suiza y acometer una remodelación interna de envergadura. Con esta advertencia, transmitida por el Archiduque a Sánchez Bella en el verano de 1957 y de la que éste daría cuenta al exministro Martín Artajo ${ }^{68}$, quedaba claro el malestar del presidente internacional del CEDI con la sección española, a la que consideraba poco operativa y excesivamente monopolizada por el grupo de Escobar ${ }^{69}$. Una óptica también compartida por Sánchez Bella, quien se esforzaría por integrar a otros colaboradores de tendencia falangista como Manuel Fraga, Diego Salas Pombo o Emilio Lamo de Espinosa ${ }^{70}$.

Asimismo, para sortear la indiferencia que Otto de Habsburgo apreciaba en el nuevo Ministro de Exteriores, Sánchez Bella ${ }^{71}$ pensó en plantear a Martín Artajo la posibilidad de asumir la secretaría internacional del CEDI como garantía para el buen funcionamiento de la asociación. Una propuesta que además ofrecía a Castiella un nombre de plena confianza para secundar las políticas del Ministerio en aquella entidad, consolidando así su influencia. En sus argumentos, Sánchez Bella reconocía que la idea del CEDI había surgido con el objetivo de «coordinar todas las fuerzas constructivas europeas que, aunque discrepantes en la distinta forma de actuar en sus países» tuvieran «el denominador común de ser antiliberales, antimarxistas, anticomunistas y antimaritainianos $\rangle^{72}$. Unos presupuestos que, en el primer y último caso, se ajustaban más al ideario de sus promotores en España que a la realidad de sus

${ }^{66}$ Carta de Alfredo Sánchez Bella a José Ignacio Escobar (14/01/1954). AGUN/ASB. Más allá de que en 1956 la organización del CEDI incluyera un centro italiano, éste nunca llegaría a constituirse como tal debido a las reservas de muchos democristianos, condicionados por la política de apertura a la izquierda de su partido.

67 WEBER, 188 (Madrid, 1994): 1092.

${ }^{68}$ Carta de Alfredo Sánchez Bella a Alberto Martín Artajo (10/07/1957). AGUN/ASB.

${ }^{69}$ ZARATIEGUI, 2010: 160-161.

70 Carta de Alfredo Sánchez Bella a Otto de Habsburgo (01/08/1957). AGUN/ASB.

${ }^{71}$ Alfredo Sánchez Bella fue designado embajador en la República Dominicana (1957) y en Colombia (1959). Entre 1962 y 1969 desempeñó dicho cargo en Italia.

${ }^{72}$ Carta de Alfredo Sánchez Bella a Fernando María Castiella (26/06/1957). AGUN/ASB. 
variadas delegaciones nacionales. No extraña entonces que los franceses, por su propia trayectoria política y cultural, asumieran en mayor o menor medida las tesis de Jacques Maritain. Una vía, en definitiva, que abogaba por una modernidad cristiana que no discutiera la laicidad del Estado ni el régimen democrático de partidos, ensamblados dentro de un humanismo atento a todas las dimensiones de la persona ${ }^{73}$. Esta síntesis de pensamiento no terminaría de encajar en las directrices señaladas por Sánchez Bella, salvo en su común oposición al comunismo y a las nociones materialistas que también pudiera sostener el liberalismo. Cosa distinta es que, en base a esas coincidencias y dentro del respeto por cada trayectoria nacional, España deseara incentivar un cambio de mentalidad entre las secciones del CEDI para amoldarlas a sus esquemas e intereses políticos. De ahí que Sánchez Bella convenciera a Castiella de los beneficios del CEDI si se reestructuraba de tal modo que tuviera una relación directa y dependiente de su Ministerio, como de hecho ocurriría. Más aún cuando en la reunión de estudios celebrada en el castillo alemán de Zeil en octubre de 1957 el CEDI decidió renovar su directiva. De hecho, se superarían con creces las expectativas del Ministerio español de Exteriores al nombrar a Alberto Martín Artajo vicepresidente internacional de la asociación, al que seguiría una segunda vicepresidencia ostentada por de la Noë y una tercera confiada al representante alemán Georg Fürst von Waldburg. Era a todas luces una medida que pretendía afianzar el apoyo oficial del Ministerio de Castiella, asegurando las dotaciones económicas que hasta la fecha habían constituido la principal fuente de financiación del CEDI ${ }^{74}$. Una subordinación que no dejaba de ser un problema para algunos de sus socios, al condicionar en exceso la operatividad de una asociación que aspiraba a hacerse presente en toda Europa. De ahí la búsqueda de vías complementarias que permitieran afianzar su autonomía en caso de que se reprodujeran nuevas crisis que amenazaran su continuidad ${ }^{75}$. Un asunto que habría de encarar la sección francesa al responsabilizarse de la presidencia internacional en 1962, después de que afloraran voces partidarias de incluir en el puesto principal del CEDI a socios de otras nacionalidades para darle un tono más democrático.

La preocupación que originó esta solicitud entre algunos miembros fundadores como Sánchez Bella, radicaba en el peligro que podía derivarse si se prescindía de una figura de consenso como la de Otto de Habsburgo. Una personalidad que, al fin y al cabo, había acreditado su capacidad de aunar a las diversas secciones nacionales, sin perjuicio de los intereses e ideas que

73 Véase MARITAIN, 1966: 62, 77-78. El propio Michelet reconocería a Maritain como «su doctor», a François Mauriac como «su guía» y a Charles Péguy como «su profeta», en CHARBONNEL, 1987: 40.

${ }^{74}$ MORENO JUSTE, 1993: 467.

${ }^{75}$ Carta de Alfredo Sánchez Bella a Otto de Habsburgo (01/08/1957). AGUN/ASB. 
inspiraban la acción del régimen. Su respuesta inicial, que pasaba por apartar a los elementos que habían auspiciado el cambio si no se avenían a reconocer la continuidad del Archiduque ${ }^{76}$, iría condescendiendo en la medida en que ya no atisbaba peligro de descomposición. De este modo, a la altura de 1959 Sánchez Bella admitiría la conveniencia de una presidencia rotatoria ocupada por los representantes de los distintos centros nacionales, siempre que se creara una presidencia honorífica y permanente para Otto de Habsburgo ${ }^{77}$. Se conciliaban así las dos tendencias. Primero, al blindar la posición del Archiduque con un título honorífico que, en todo caso, no le despojaba de su poder decisorio con derecho nato de asistencia. Una autoridad compatible con la creación de una presidencia ejecutiva renovable cada dos años ${ }^{78}$. Y es que, a su juicio, con este nuevo organigrama parecía llegada la hora de centrar los trabajos del CEDI hacia una actitud más práctica en el planteamiento de los problemas. Se trataba de fijar un objetivo claro para convertir la asociación en un auténtico referente de la política europea ${ }^{79}$.

Hacia esa dirección se encaminaría la presidencia de Alberto Martín Artajo después de que se recompusiera el Comité, oído el parecer del Archiduque para infundir mayor vitalidad al CEDI. La confluencia de pareceres en el VIII Congreso celebrado en el Valle de los Caídos en septiembre de 1959, aproximaría considerablemente los centros de Francia y España al asumirse oficialmente el modelo gaullista de confederación europea ${ }^{80}$. Mucho influyó que en el año anterior los gaullistas tomaran las riendas del gobierno, entre los que sobresaldrían varios socios del CEDI, como bien destacaron algunos informes diplomáticos ${ }^{81}$. Tanto la nueva posición de Edmond Michelet, designado Ministro de Antiguos Combatientes hasta hacerse con la cartera de Justicia en la remodelación de 1959, como François de la Noë, elegido consejero técnico del Ministerio de Asuntos Exteriores, les permitiría atraer a otros colegas del gabinete a su sección, como sería el caso de Michel Debré, nombrado Primer Ministro hasta 1962. La presencia de estas personalidades en los circuitos de poder de un Estado fundador de la CEE, con peso suficiente como para promover un proyecto propio en Europa, les catapultó a la primera línea del CEDI debido a la mayor repercusión que podían alcanzar sus propuestas. A la mejora de las relaciones bilaterales y la correspondencia española a varios postulados gaullistas sobre la política europea y de defensa, se sumó el apoyo

${ }^{76}$ Carta de Alfredo Sánchez Bella a Otto de Habsburgo (16/07/1958). AGUN/ASB.

77 Carta de Alfredo Sánchez Bella a José Ignacio Escobar (30/11/1959). AGUN/ASB.

${ }^{78}$ Carta de Alfredo Sánchez Bella a José Ignacio Escobar (30/11/1959). AGUN/ASB.

${ }^{79}$ Carta de Alfredo Sánchez Bella a José Ignacio Escobar (30/11/1959). AGUN/ASB.

${ }^{80}$ GAUPP-BERGHAUSEN, 1971: 223.

81 VIII Congresso CEDI (09/10/1959). AMAE, Uffici Politici, 1945-1960, Versamento I, caja 315 . 
galo para que el CEDI pudiera desarrollar con normalidad las jornadas de trabajo organizadas en Bruselas en octubre de 1958 y sortear así la oposición mostrada por el presidente del Consejo Europeo. A pesar de los desvelos confesados por Otto de Habsburgo para salvar la posición de España en la capital belga $^{82}$, Sánchez Bella repuso que entre las razones del CEDI no se encontraba la defensa de España, sino la movilización de las fuerzas cristianas y anticomunistas con las que preparar una doctrina común ${ }^{83}$. Se trataba, en definitiva, de propagar esos principios entre los distintos gobiernos y parlamentos, sustrayendo a los sectores afines de influjos liberales para insertarlos en la órbita de un pensamiento tradicionalista renovado ${ }^{84}$. En otras palabras, plantear una alternativa al liberalismo europeo desde una óptica íntegramente católica con la que servir a los intereses del régimen español ${ }^{85}$. Ciertamente, en ese contexto de marginación, Sánchez Bella era consciente de las escasas posibilidades que tenía España para hacer valer su voz en las instituciones europeas, inclinándose por trasladar la sede directiva del CEDI a París. Tal como indicaría al Ministro Castiella, esa opción permitiría al CEDI competir más eficazmente con otros movimientos europeístas sin hipotecas que minaran su credibilidad $^{86}$.

\section{LA PRESIDENCIA DE EdMOND Michelet (1962-1964)}

En la convocatoria de la reunión del Consejo Internacional del CEDI en París durante el mes de diciembre de 1961, ya se atisbó un cambio de tendencia algo más despegado del protagonismo que había adquirido España, al presidir Edmond Michelet el pleno de las sesiones. Una iniciativa tomada a propuesta de François de la Noë87 y que culminaría con el relevo de Alberto Martín Artajo en la presidencia internacional apenas seis meses después. El visto bueno a esta remodelación por parte de la delegación española, respondía al interés de Exteriores por subrayar la internacionalidad del CEDI e incrementar su eficacia en apoyo a la solicitud de asociación de España al Mercado Común, cursada en febrero de 1962. Sobre todo si el que presidía era pieza importante de la estructura del poder gaullista, designado miembro del Consejo Constitucional ${ }^{88}$ de un Estado que, por su afán de liderazgo europeo,

82 Carta de Otto de Habsburgo a Alfredo Sánchez Bella (17/10/1958). AGUN/ASB.

${ }^{83}$ Carta de Alfredo Sánchez Bella a Otto de Habsburgo (25/10/1958). AGUN/ASB.

${ }^{84}$ Carta de Alfredo Sánchez Bella a Otto de Habsburgo (25/10/1958). AGUN/ASB.

85 SENANTE, 2007: 266.

${ }^{86}$ Carta de Alfredo Sánchez Bella a Fernando María Castiella (01/02/1962). AGUN/ASB.

${ }^{87}$ Lettre de François de la Noë à Edmond Michelet (24/10/1961). AEM. 05. 122/01.

${ }^{88}$ CHARBONNEL, 1987: 123. 
respaldaba por esas fechas la candidatura de Madrid a la Comunidad Europea. De hecho, ya en marzo de 1962, antes de que se diera cita el Comité de dirección del CEDI en Salzburgo, Michelet aceptó la posibilidad de asumir el cargo, tal como le había sugerido de la Noë con el beneplácito de Otto de Habsburgo y los representantes españoles. De este modo, previendo una reorganización que ya se había considerado en la asamblea preparatoria del XI Congreso del CEDI ${ }^{89}$, el presidente de la sección francesa propuso a Michelet que asumiera la primera vicepresidencia ${ }^{90}$. Más aún al coincidir con la dura reacción de Madrid en contra de los participantes españoles en el IV Encuentro del Movimiento Europeo celebrado en Munich en junio de 1962, y que dañaría nuevamente la imagen del régimen en el exterior. En este contexto, mucho influyó la necesidad de guardar una apariencia más autónoma para que el CEDI fuera más efectivo en sus objetivos, que se mantuvieron inalterables $^{91}$. Especialmente después del éxito que supuso para la diplomacia franquista la aprobación del Informe Macmillan por parte de la Comisión Política del Consejo de Europa en mayo de 1962, al recomendar a los gobiernos de la CEE que estudiaran alguna forma de acuerdo económico con España, a la espera de que se produjeran algunas modificaciones constitucionales que permitieran su plena asociación ${ }^{92}$. Un cambio sustancial en relación con la actitud desfavorable recogida en el Informe Renger en enero de 1962, cuya neutralización se debió en gran medida a la acción de ciertas personalidades del conservadurismo europeo ${ }^{93}$, apoyada por algunos miembros del CEDI bien posicionados en sus gobiernos. De hecho, en su intervención de clausura, antes de tomar el testigo de Martín Artajo en El Escorial, Michelet reclamaría públicamente y sin paliativos el ingreso de España en la Comunidad Europea, en línea con la opinión de su gobierno ${ }^{94}$. Entre otras cosas, por el espaldarazo que supondría para Francia en su afán de liderazgo del proceso de construcción europea y por la impronta cristiana que el país ibérico podía aportar a la cultura del continente ${ }^{95}$.

Iniciada la presidencia de Michelet en el verano de 1962, se activaría una frenética labor espoleada por François de la Noë para hacer efectiva la pujan-

89 Ordre du jour pour le Comité de Direction du CEDI (09/06/1962). AEM. 05. 130/063.

${ }^{90}$ Lettre de François de la Noë à Edmond Michelet (01/03/1962). AEM. 05. 127/01.

${ }^{91}$ En el informe remitido por la embajada italiana en Madrid se insistía en la férrea posición anticomunista de la asociación y en su defensa de los valores cristianos como elementos configuradores del orden europeo y occidental. AMAE, Uffici Politici, 1945-1960, Versamento II, caja 141.

${ }^{92}$ MORENO JUSTE, 1998b: 254.

${ }^{93}$ Véase la nota informativa de la Dirección General de Política Exterior del Ministerio de Asuntos Exteriores en MORENO JUSTE, 1998b: 255.

${ }^{94}$ FLEITES MARCOS, 2009: 205.

95 Discurso de Michelet en XI Réunion du CEDI (22-24 juin1962), 1964: 250. 
za francesa al frente del CEDI. Entre las distintas medidas enunciadas, se contaban el intento por trasladar permanentemente la secretaría internacional a París y ampliar los cauces de financiación por otras vías complementarias que implicaran al gobierno galo ${ }^{96}$. Para ello, de la Noë no dudó en sacar partido de su condición de consejero del Ministerio de Exteriores. Primero, apelando al director del gabinete de la Secretaría de Estado para que se incrementaran las subvenciones al CEDI, además de movilizar a los servicios de la embajada en Madrid para concertar encuentros en su sede con los principales estamentos dirigentes del país ${ }^{97}$. Asimismo, lograría un acuerdo con von Gaupp para instalar el secretariado general en la capital del Sena a partir de octubre de aquel año, atendiendo a las necesidades de la nueva presidencia gala ${ }^{98}$.

Sin embargo, el discreto aumento de las dotaciones presupuestarias tendría un recorrido más bien efímero, al interponerse una reducción en las partidas que se agravaría cuando la presidencia internacional pasó a manos del democristiano alemán von Merkatz en 196499. Una dificultad que de la Noë compensaría parcialmente al conseguir el traslado provisional de la secretaría internacional a París, aunque no pudiera hacerse con su dirección ${ }^{100}$. De todos modos, su puesto al frente del centro nacional francés, en el que ahora pivotaba la principal actividad del CEDI, permitiría proceder a una reorganización logística con una inyección suplementaria de capital para mejorar las retribuciones a los conferenciantes y atraer otros nuevos ${ }^{101}$. En este sentido, subrayaría la necesidad de una mayor cooperación entre secciones para asentar la perspectiva de una visión cristiana de la historia y la sociedad - aspecto reivindicado por Michelet-, sin merma en la libertad e independencia de cada centro nacional a la hora de fijar sus particulares líneas políticas o económi-

${ }^{96}$ Lettre de François de la Noë à Edmond Michelet (04/09/1962). AEM. 05. 129/09.

${ }^{97}$ Lettres entre François de la Noë et les ambassadeurs à Madrid, Armand du Chayla et Robert de Boisséson (23/05/1962; 12/06/1964). ADF 396/PO/F/1-1476. Série IX, nº 1100.

${ }^{98}$ Lettre de François de la Noë à Edmond Michelet (04/09/1962). AEM. 05. 129/09.

${ }_{99}$ A pesar de lo dicho, no debiera concluirse que el relevo de Michelet —en aplicación del sistema rotatorio-, fuera determinante para explicar la disminución de las ayudas económicas por parte del gobierno de París. Sobre todo porque los problemas de asistencia oficial se trasladarían al propio centro nacional francés a lo largo del tiempo, como prueban las constantes quejas de la Noë y su insistencia a Michelet para que presionara a sus colegas de gabinete desde que en 1967 reasumiera funciones ministeriales. El apoyo del gobierno era más la consecuencia del compromiso ineludible con algunos próceres de su corriente democristiana, implicados en las tareas del CEDI, que en el interés certero por una organización que no le era imprescindible para sostener la estrategia global de su política europea. Acerca de esta cuestión pueden consultarse la relación de lettres adressées pour François de la Noë à Edmond Michelet et Georg von Gaupp entre 1965 et 1967, en AEM. 05. 129/014/015/017/021.

${ }^{100}$ Lettre de François de la Noë à Edmond Michelet (04/03/1963). AEM. 05. 129/011.

${ }^{101}$ Lettre de François de la Noë à Pierre Juillet (17/01/1963). AEM. 05. 129/013. 
cas $^{102}$. Y es que realmente subyacía la voluntad de unir esfuerzos entre movimientos europeístas más o menos parecidos bajo el liderazgo del CEDI. Poco antes de su XII Congreso, reunido en El Escorial en junio de 1963, se había hecho balance de las numerosas actividades desplegadas durante la anualidad precedente. Allí se repasó el estado de las cuentas, que arrojaban una cifra de 41.727 marcos alemanes para cubrir los gastos de la organización, ingresados en concepto de donaciones y préstamos bancarios ${ }^{103}$. Desglosado por países, despuntaba la contribución del centro alemán con un total de 10.000 marcos, seguido por Francia con un volumen de 4.904104. Paradójicamente, España no figuraba en dicho bloque al asumir de modo íntegro los gastos más cuantiosos referidos a congresos, excursiones y publicaciones anuales del CEDI. Todo ello a pesar de que la situación financiera de su sección nacional no fuera de las más boyantes, con una cantidad estimada de 2000 marcos, al igual que Liechtenstein o Portugal ${ }^{105}$. La financiación se completaba con un montante de 11.361 marcos procedente de ingresos privados a la secretaría general y a la presidencia de honor. En este sentido, es probable que España aportara alguna cantidad siguiendo los parámetros de su diplomacia informal para influir de manera indirecta en las labores de la organización ${ }^{106}$. Unas cifras que mejorarían al año siguiente con un incremento de 9000 marcos hasta alcanzar la cantidad de 50.428, de los que España seguiría asumiendo los costes logísticos mientras Francia haría lo propio con los de mantenimiento al abonar las facturas de electricidad, calefacción, teléfono e impresión ${ }^{107}$. Con este reparto de responsabilidades se emprendió el despliegue del Congreso Internacional de 1963 que presidiría Edmond Michelet, después de ignorar las críticas de gran parte de la opinión pública europea por la ejecución de Julián Grimau en el mes de abril. También por la propia inhibición del General De Gaulle, que no intervino para que su Ministro de finanzas, Valéry Giscard d'Estaing, suspendiera la visita oficial a España debido a los intereses económicos en juego ${ }^{108}$. Un extremo que también apuntaría François de la Noë, poniendo como ejemplo la actitud impasible del gobierno de Bonn, guiado por criterios de mercado que marginaban las cuestiones más ideológicas ${ }^{109}$. Opinión compartida por Michelet, que en ningún caso se plan-

\footnotetext{
102 Projet adressé à la Commission du CEDI (1962). AEM. 05. 130/104.

${ }^{103}$ Comptes des profits et pertes (janvier-décembre, 1962). AEM. 05. 130/068/069.

104 Dons et contributions. AEM. 05. 130/070.

${ }^{105}$ Rapport du Secrétariat Général sur la situation financière et le travail depuis le ler janvier 1963. AEM. 05. 130/071.

106 MORENO JUSTE, 1993: 465, 467.

${ }^{107}$ Rapport du Secrétariat Général sur la situation financière depuis le 1 juin 1963. AEM.

108 SÁNCHEZ, 2006: 204.

${ }^{109}$ Lettre de François de la Noë à Edmond Michelet (1963). AEM. 05. 136/06.
} 05. 130/098. 
tearía suspender o aplazar un congreso impulsado por el conjunto de las delegaciones nacionales del CEDI. Más aún, admitiendo otra vez la necesidad de ampliar el círculo de Estados miembros de la Comunidad Europea sin caer «d'hypocrites arguments idéologiques pour faire attendre plus longtemps tel ou tel pays dont $1^{\prime}$ Europe a besoin pour être vraiment $1^{\prime}$ Europe» ${ }^{110}$. Y es que para Michelet, tal como había expuesto en otras ocasiones, la construcción europea sólo podría realizarse a partir de la aportación de cada una de sus patrias en base a una cultura cristiana común que rechazaba toda perspectiva marxista ${ }^{111}$.

La presencia del secretario general de la gaullista Union pour la Nouvelle République, Jacques Baumel, junto a destacadas figuras de la familia democristiana como Christian de la Malène, Paul Palewski o el vicesecretario de Estado francés de Asuntos Exteriores, Michel Habid-Deloncle, que no pudo asistir por motivos de agenda ${ }^{112}$, revelan un mayor protagonismo de la sección francesa del CEDI. Así lo manifestaría la embajada en Madrid al concluir que el encuentro había cumplido con su utilidad. Tanto por las críticas vertidas por los delegados franceses contra el marxismo, como por el valor de una cita internacional que permitía propagar nuevamente las ideas de París sobre Europa ${ }^{113}$. Un empeño al que se sumaron las 23 conferencias que impartió Michelet en varias ciudades españolas, tratando los hitos fundamentales del pensamiento gaullista y la vocación de Europa, en línea con las resoluciones adoptadas por el CEDI ${ }^{114}$.

Con el nuevo año se encaró el próximo relevo de Michelet al frente de la presidencia, no sin que antes fuera condecorado por Franco con la Gran Cruz de San Raimundo de Peñafort por su trayectoria y méritos en la dirección del $\mathrm{CEDI}^{115}$. La convocatoria en París a finales de febrero de 1964 de una Asamblea General que renovaría la Comisión, elaborando un programa político para tratar en el Congreso Internacional los aspectos de la distensión, confirmaron la elección de Hans-Joachim von Merkatz como nuevo presidente. Por su parte, las tres vicepresidencias se distribuirían entre Edmond Michelet, restituido en su antiguo puesto, Alberto Martín Artajo y el británico John Rodgers en la segunda y tercera vicepresidencia ${ }^{116}$. Asimismo, se procedió a

${ }^{110}$ Intervención de Michelet en XII Réunion du CEDI (08-10 juin de 1963), 1964: 163.

111 GONZÁLEZ CUEVAS, 13 (Torino, 1998), 58. Declaraciones de Michelet al Diario de Mallorca (11/11/1963).

112 Lettre de Michel Habid-Deloncle à Edmond Michelet (05/06/1963). AEM. 05. 131/04.

${ }_{113}$ Note au Ministre des Affaires Étrangères (juin, 1963). ADF 396/PO/F/1-1476. Série IX, $\mathrm{n}^{\mathrm{o}} 1100$.

114 Notes de conférences. AEM. 04. 1314/02/08.

115 Decreto de concesión de la Gran Cruz de San Raimundo de Peñafort a Edmond Michelet (23/01/1964). AEM. 05. 129/04.

116 Projet relatif à l'éléction du Président et des 3 viceprésidents. AEM. 05. 130/103. 
la remodelación de algunas delegaciones como la francesa, en la que Michelet pasaría a ostentar su dirección, siempre asistido por de la Noë y HabidDeloncle $^{117}$. De este modo, para julio de 1964 ya se había reconfigurado el Comité central del CEDI, cuya principal preocupación giraría en torno a la sucesión generacional recogida en un extenso memorándum elaborado por su secretario general, Georg von Gaupp ${ }^{118}$. En sus páginas se advertía la necesidad de entablar un diálogo intergeneracional para evitar anquilosamientos que restaran efectividad al discurso y a las propuestas del CEDI en la formación político-intelectual de la juventud. Se incidía además en el modo de dar cabida a ese colectivo mediante la creación de secciones juveniles en cada centro nacional. Cuestión que se formalizaría en el XIV Congreso reunido en Santiago de Compostela, al ceder la palabra a un grupo nutrido de jóvenes organizados por delegaciones y que participarían en calidad de ponentes para exponer sus ideas sobre Europa ${ }^{119}$. Una oportunidad que, a juicio del Conde de la Noë, no debía desaprovecharse ante la previsión del importante volumen de las delegaciones juveniles procedentes de Alemania y el Reino Unido. Al espolear la logística de la embajada en España para que acogiera a un amplio cuadro de jóvenes franceses en el encuentro, de la Noë confirmó su propósito de asegurar la continuidad a la idea de Europa que había sostenido su delegación desde los orígenes ${ }^{120}$.

Con todo, a pesar de los intentos por regenerar la organización de cara al futuro, la pérdida de algunos dirigentes de entidad como el propio de la Noë, fallecido en 1968, o la Edmond Michelet en 1970, erosionarían un proyecto cada vez más desplazado por la preeminencia del pensamiento liberal en la definición del modelo europeo. Un proceso que se agravaría con el atisbo de renuncia — que no llegó a hacerse efectiva - de von Gaupp a la secretaría general en enero de $1969^{121}$. En realidad, se trataba de uno de los últimos intentos por actualizar una organización que ya no contaría con el apoyo decidido de España a partir de 1975. El objetivo por homologarse políticamente a los países de la CEE conllevó la progresiva retirada de las ayudas económicas al CEDI, debido a su identificación con un sistema de ideas contrapuesto a la lógica de la transición democrática, que beneficiaría a otros movimientos plenamente integrados en las premisas inspiradoras de dicho proceso. 130/102.

${ }^{117}$ Suggestion de la Commisssion pour l'election du Comité de Direction. AEM. 05.

118 Aux centres nationaux. La jeune génération du CEDI (30/09/1964). AEM. 05. 130/110-114.

119 GAUPP-BERGHAUSEN, 1971: 454-455.

${ }^{120}$ Lettre de François de la Noë à Robert de Boisséson, ambassadeur à Madrid (16/06/1965). ADF. 396/PO/F/1-1476. Série IX, nº 1100.

${ }^{121}$ Lettre de Georg von Gaupp au Comité du Direction du CEDI (27/01/1969). AEM. 04. 905/058/059. 


\section{Conclusiones}

Aunque la idea de crear el CEDI correspondió a varios dirigentes de la Acción Católica que colaboraron con el régimen de Franco, lo cierto es que concitó prontas adhesiones entre la derecha europea más complaciente con la España oficial. Y es que la apelación a la defensa de los valores cristianos de Europa como premisa para forjar su unidad desde el respeto a las soberanías nacionales, sentaron las bases para una paulatina convergencia con otros grupos conservadores del continente. Al actuar de plataforma para establecer contactos personales, los promotores del CEDI se proponían allanar el camino para difundir los principios que informaban el sistema político español. En el fondo, anidaba la pretensión de acrisolar a las corrientes conservadoras europeas en las pautas ideológicas del tradicionalismo. De ahí sus intentos por involucrar en ese objetivo a otros movimientos europeos como la Unión Paneuropea o el Comité para la Defensa de la Civilización Cristiana, que acabarían proporcionando algunos nombres eminentes en la constitución del CEDI. Su propósito por inmunizar a ciertos grupos afines de la influencia de las tesis liberales, radicaba en el perjuicio que éstas podían ocasionar a su proyecto político de construcción europea. Si bien es verdad que siempre convivieron múltiples pareceres entre las distintas delegaciones nacionales en cuanto al modo de encarar esos fines, con el tiempo fueron perfilándose unas posturas cada vez más comunes. No fue casual que, dentro de esas pautas generales, se impusiera la no injerencia en la política interna de los Estados. En realidad, se propugnaba una vía unitaria en la que las soluciones supranacionales y políticamente uniformes serían relegadas por el principio de subsidiariedad como fundamento para la cooperación entre los Estados. Es aquí cuando fue tomando forma el concepto de «Europa de las patrias» sostenido por el gaullismo y que sería adoptado por el CEDI para favorecer los anhelos de España en su intento por ensamblarse a Europa sin modificar la sustancia ideológica del régimen. El ascenso de la sección francesa a la dirección del CEDI no responde, por tanto, a una lucha interna de poder con el centro español. Al contrario, el cambio de protagonismo en beneficio de los franceses respondió a una estrategia premeditada por parte de sus socios fundadores y del Ministro español de Asuntos Exteriores, para tomar en provecho propio la fuerza de París en la CEE. Esto explica el nombramiento de Edmond Michelet como presidente del CEDI en 1962, coincidiendo con la solicitud de asociación de España al MEC. Y es que el objetivo consistía en subrayar el carácter internacional de la asociación, desvinculándola de percepciones monopolizadoras que pudieran perjudicar los intereses de España y la credibilidad del propio Centro.

Sin embargo, esto no quiere decir que la delegación francesa se limitara a conservar las apariencias. Desde un comienzo se afanó para que el CEDI actua- 
ra como caja de resonancia de la política del gobierno francés en Europa, recurriendo a la asistencia extraoficial de sus servicios diplomáticos. Ese intento por sostener el discurso gaullista en el continente, exigió ampliar las fuentes de financiación a través de las instituciones francesas, superando la excesiva dependencia de los recursos dispuestos por España. En último término, se trataba de que la asociación ganara en autonomía e internacionalidad, reduciendo la dependencia financiera con respecto al régimen franquista. El refuerzo de las propuestas unitarias a partir de la cooperación soberana de los Estados de Europa y la corresponsabilidad en la gestión del CEDI, fueron las principales aportaciones de la delegación francesa en la trayectoria de dicho movimiento.

\section{BibLIOGRAFÍA}

Álvarez Junco, José, Mater dolorosa. La idea de España en el siglo XIX, Madrid, Taurus, 2001.

Boninchi, Marc, Vichy et l'ordre moral, París, PUF, 2005.

Charbonnel, Jean, Edmond Michelet, París, Beauchesne, 1987.

Charlot, Jean «Le gaullisme» en Sirinelli, Jean-François (dir.), Histoire des droites en France, París, Gallimard, 1992; 653-689.

CEDI: lo que es, lo que hace, cómo funciona, Madrid, 1956.

Cointet, Michèle, Nouvelle histoire de Vichy, París, Fayard, 2011.

Coudenhove-Kalergi, Richard, Paneuropa, Madrid, Tecnos, 2002.

De la Noë, François, Christianisme et politique, París, Beauchesne, 1947.

De la Noë, François, Le Christianisme peut-il nous sauver? París, La Colombe, 1949.

De la Noë, François, (Dupeyrat, André), Sainteté «au naturel», París, Fayard, 1957.

Fazio, Mariano, Secularización y Cristianismo, Buenos Aires, Universidad Libros, 2008.

Fernández Miranda, Torcuato, El problema político de nuestro tiempo, Madrid, Alférez, 1950.

Fleites Marcos, Álvaro, De Gaulle y España, Avilés, Azucel, 2009.

Fogarty, Michael, Historia e ideología de la Democracia Cristiana en la Europa occidental, 1820-1953, Madrid, Tecnos, 1964.

Gaupp-Berghausen, Georg von (comp.), 20 años de CEDI, Madrid, Editora Nacional, 1971.

González Cuevas, Pedro Carlos «Neoconservatismo e identidad europea. Una aproximación histórica», Spagna contemporánea, 13, (Torino, 1998), 41-60.

Habsburgo, Otto, «Misión del intelectual en el mundo moderno», Cuadernos Hispanoamericanos, 62, (Madrid, 1955), 147-161.

Juliá, Santos, «Intelectuales católicos a la reconquista del Estado», Ayer, 40, (Madrid, 2000), 79-103.

Maritain, Jacques, Humanismo integral, Buenos Aires, Editorial Carlos Lohlé, 1966. Martín de la Guardia, Ricardo; Pérez Sánchez, Guillermo, La Unión Europea y España, Madrid, Actas, 2002. 
Mayeur, Jean-Marie, Des partis catholiques à la Démocratie Chrétienne, París, Armand Colin, 1980.

Moreno Juste, Antonio, «El CEDI. Un intento fallido de aproximación a Europa, 1952-1962» en Javier Tusell (ed.), El régimen de Franco (1936-1975). Política y relaciones exteriores, vol. 2, Madrid, UNED, 1993; 459-474.

Moreno Juste, Antonio, España y el proceso de construcción europea, Barcelona, Ariel, 1998a.

Moreno Juste, Antonio, Franquismo y construcción europea (1951-1962), Madrid, Tecnos, 1998b.

Moreno Juste, Antonio, «La política europea de los católicos españoles en los años 40 y 50» en Glicerio Sánchez Recio, (coord.), La Internacional Católica. Pax Romana en la política europea de posguerra, Madrid, Biblioteca Nueva, 2005; 175-211.

Payne, Stanley, El régimen de Franco, Madrid, Alianza, 1987.

Pereira, Juan Carlos, «Los Estudios Internacionales en España: la política exterior» en Pereira, Juan Carlos (coord.), La política exterior de España, Barcelona, Ariel, 2010; 55-82.

Pérez-Bustamante, Rogelio, Historia politica de la Unión Europea, 1940-1945, Madrid, Dykinson, 1995.

Pérez-Maura, Ramón, Del Imperio a la Unión Europea. La huella de Otto de Habsburgo en el siglo XX, Madrid, Rialp, 1997.

Pío XII, «Benignitas et humanitas», 5, (1944), en Colección de encíclicas y documentos pontificios, vol. 1, Madrid, Junta Nacional de Acción Católica, 1967.

Powell, Charles «España en Europa: de 1945 a nuestros días», Ayer, 49, (Madrid, 2003), 81-119.

Prades, Sara, «Escribir la Historia para definir la nación. La historia de España en Arbor: 1944-1956», Ayer, 66, (Madrid, 2007), 177-200.

Redondo, Gonzalo, Política, cultura y sociedad en la España de Franco. La configuración del Estado español, nacional y católico (1939-1947), vol. 1, Pamplona, Eunsa, 1999.

Rémond, René, La droite en France, vol. 2, París, Aubier, 1968.

Réunion (XI) du CEDI (22-24 Juin, 1962), Le problème social à l'échelle international, Madrid, 1963.

Réunion (XII) du CEDI (08-10 Juin, 1963), Europe, en mutation, 1964.

Sánchez Bella, Alfredo, «Franco y la cultura», Razón Española, 14 (Madrid, 1985), 273-294.

Sánchez, Esther, Rumbo al sur. Francia y la España del desarrollo, 1958-1969, Madrid, CSIC, 2006.

Senante, Heidy-Cristina, «España y Europa: el camino hacia la integración» en Foner, Salvador (ed.), La construcción de Europa: de las "guerras civiles» a la «unificación», Madrid, Biblioteca Nueva, 2007; 263-280.

Sesma Landrín, Nicolás, «La construcción del discurso europeísta del franquismo desde el Instituto de Estudios Políticos (1948-1956)», Historia Contemporánea, 30, (Bilbao, 2005), 159-177. 
Tusell, Javier, Franco y los católicos. La política interior en el régimen de Franco, Madrid, Alianza, 1984.

Weber, Petra-María, «El CEDI. Promotor del occidente cristiano y de las relaciones hispano-alemanas de los años cincuenta», Hispania, 188 (Madrid, 1994), 1077 1103.

Zaratiegui, Jesús María, Una Europa para dos Españas. Primeros pasos hacia la integración (1957-1963), Pamplona, Eunsa, 2010.

Recibido: 22/10/2014

Aprobado: 29/12/2015 